\title{
Prefects in Search of a Role in a Europeanised France
}

\author{
ALISTAIR COLE European Studies, Cardiff University
}

\begin{abstract}
Based on extensive new empirical fieldwork (via a case study of the reform of the territorial State in 2007-2010), this article interrogates the meaning of the prefectoral institution in France. The central puzzle this article addresses is the survival of a pre-democratic institution - the Prefect in - a democratic, decentralizing and Europeanised Republic. Changing conditions have required institutional resilience and adaptation in a period of state restructuring and rescaling. The case study of the prefectures as old institutions is framed using language and tools of new institutionalism across three dimensions: the timing and sequence of decision-making, the logic of appropriateness, and interaction. Beyond the narrow case of the prefectures in France, the article makes the case for combining modes of institutionalist analysis in order to penetrate generalities about the black box of institutions.
\end{abstract}

Key words: France, prefects, decentralisaton, Europeanisation

The central puzzle of this article is the survival of a 200 year old institution the prefect - in the context of a democratic, decentralizing and Europeanised French Republic. The key justification for the institution has shifted over time. Far from the quasi-military logic inherent in the Napoleonic model, France's contemporary prefects have justified their existence through notions related to the horizontal coordination of the State, partnership with local and regional authorities and orchestration of France's interactions with the European Union in the field of regional policy. Insofar as the State still seeks a presence throughout France, however, it is physically embodied in the figure of the prefect, who can claim to represent the symbolic institutional continuity of the State. The article does not seek to offer an exhaustive history of the prefectoral institution (see for example Tanguy 2009; Le Lidec 2007; Kerrouche 1997; Grémion 1976; Worms I966; and for a small number of works in English that have stood the test of time see Chapman i955; Machin 1976), but rather looks at fresh empirical evidence drawn mainly (though not entirely) from the 2007-2010 period of far-reaching political and administrative reform. 
This case study is designed to allow more general lessons to be drawn about the variable contexts and forms of multi-level governance in Europe (Piattoni 2010). Contemporary France lies in the shrinking camp of unitary decentralised states (Pinson 2010; Pasquier 2009; Le Galès 2008; Thoenig 2005; Delcamp and Loughlin 2002) French regions lack the law-making powers of counterparts in Germany, Spain, Italy or the devolved governments in the UK. But our study demonstrates that outcomes can and do vary according to territorial configurations. The processes described in the first part of the article validate arguments based on a modified version of multi-level governance, understood in terms of Piatonni's three axes of internal decentralisation, domesticinternational pressures and reconfigured state-society relations (Piattoni 2010). The main challenges to this modified version of multi-level governance are discussed in part two, which explores the use of managerial and fiscal policy instruments of the type that have a more general resonance across Europe.

Against the general background of multi-level governance, the article addresses the core research question of the conditions for institutional resilience and adaptation in a period of state restructuring and rescaling, where resilience is defined in terms of long-term organisational survival and adaptability is framed as adjusting to new roles. To make sense of the prefectures as institutions, we combine empirical observation with the insights of new institutionalism, a broad body of theory that facilitates an understanding of the varied facets of the prefectures as organizations. For the purposes of analytical clarity, we identify three distinctive dimensions in the new institutionalist literature that encompass the values and interests of actors (appropriateness or sense-making), the temporalities of institutional design (decision-making) and the interdependent relationships that, in practice, constrain the operation of institutions (interactions).

\section{Networked Institutionalism and the evolution of a territorial public space}

The three dimensions of sense-making, decision-making and interaction respond to key roles that are performed in the prefectures. In this section, we present the French prefectures mainly in terms of their interactions beyond the State, concentrating on the development of a territorial public space from the early ig8os. The approach we label as networked institutionalism insists upon formal and informal modes of institutionalization of interorganisational dynamics (Cole and John 200I; Peters 1999). The next section offers a more detailed analysis of the 2007-2010 reform from the prism of models of decision-making and norms of appropriate behaviour.

\section{The Temporal Dimension}

Reasoning in terms of the temporalities of institutional design requires a fine-grained understanding of historical settings. From the perspective of 
the historical longue durée, the core legitimacy of the prefect has been derived from representing the French State in its territories, rather than symbolizing a particular regime. Though the prefect came to embody a certain conception of the Republic, the origins of the institution lie in the imperial Napoleonic regime, and prefects have served the state under Republics, Empires and the wartime Vichy regime as well (Pontier 20I0). The prefect was created by Napoleon in I80o to represent the State in each of the then 90 départements in metropolitan France. In the Revolutionary-Napoleonic tradition, the role of the locality was, as Hayward (1983) put it, to integrate the periphery in a centralized system. The (departmental) prefect was, in theory, the pivot of this system of territorial administration. He represented the central state in French localities and was charged with controlling local communes, implementing central government policies and maintaining public order. If the apogee of the prefectoral institution was during the Second Empire (1852-1870), the institution had to adapt to the slow consolidation of French local democracy with the I87I (departmental) and I884 (municipal) Acts (Mabileau I99I). In his detailed study, Machin (1976) contrasted the myth of an omnipresent state official with the reality of a politically emasculated and subordinate 'parliamentary' prefect in the third and fourth Republics. For most of the past two centuries, central government did not want the prefects to become too powerful, because they might recreate the powerful baronies of the ancien regime. Prefects were encouraged to refer up to Paris for even minor administrative decisions, in practice reducing their capacity to exercise territorial leadership. Herein lies the essential ambivalence of the prefectoral institution, whose capacity for action has ultimately rested as much upon territorialized relationships as on formal roles and rules.

A rather different perspective on the historical longue durée concerns the contextually rich accounts of local politico-administrative relations provided by organizational sociologists, writing in the ig6os and I97os but referring mainly to the pre-I940 period. The 'cross-regulation' approach developed by Crozier and Thoenig (1975) provided the fullest account of relations between local political and administrative actors. There was an ongoing interaction between state officials (notably the prefect) and leading local politicians, confirming that the State was unable to exercise a genuine territorial control without the support of the political barons known as notables. Relationships were limited to a 'dual elite' of political and administrative actors; there was no place for 'third parties, whether they be economic interests or voluntary associations' (Duran and Thoenig I996: 588). There was an incentive for ambitious politicians to accumulate elective offices (cumul des mandats) as office gave access to higher levels of authority and consolidated local power bases. A similar framing of informal institutionalization was that of 'tamed Jacobinism' (Grémion I976), 
whereby prefects and notables struck compromises to adapt national policy to local circumstances. Underpinning these accounts is the observation that prefects have always had to accommodate local political forces. The metaphor of cross regulation left a powerful legacy in the study of French inter-governmental relations, and still today is used as shorthand to refer to such pervasive practices as multiple office holding (cumul des mandats), the tradition of appealing to higher placed levels of authority for arbitration, and the dynamic of cooperation and competition between territorial political and administrative elites.

Two parallel, yet distinctive processes occurred in the first decade after I958; the promotion of a coordinating role for the departmental prefect over field services in the département and the emergence of a regional level as a space for public policy (Machin I976). Ultimately, the latter was of more significance. The modernizing postwar state looked to the regional space, not the départements, to provide the institutional basis for regional economic planning (Burnham 2009). The regional prefectures (created in I964) were at the heart of this regionalisation strategy. Functional regionalisation helped to define the regional space in terms of an economic, rather than a political space, and a policy making space, rather than a 'normative' one (Pasquier 20I0). But at least it laid the bases for the later development of a regional public sphere. Initially limited in their scope, the regional prefectures have developed key resources since the early ig8os as a result of the (separate but linked) processes of political and administrative decentralisation, stateregional planning and the implementation of EU regional policy, three dimensions of negotiated interactions that we now consider.

\section{Decentralisation}

The post-I982 period provided the context for adapting and rescaling the outmoded 'cross regulation' model to a form of multi-level governance. The complex political decentralization reforms of 1982 eventually aligned France with the core principles of the Council of Europe's European Charter of Local Autonomy that she finally signed in 2007 (SchondorfHaubold 2007). Political decentralization took the form of the creation of 22 elected regional councils, with what were initially perceived to be rudimentary powers. The 1982 law also greatly enhanced the decision-making powers of the 96 departmental councils (created by the Revolution) and of the larger communes. A constitutional amendment of 2003 declared that France was henceforth a 'decentralised Republic' and embedded further the legal and financial rights and responsibilities of local and regional authorities. In practice, the various sub-national authorities have overlapping territorial jurisdictions and loosely defined spheres of competence. Moreover, there is no formal hierarchy among them. Unlike in federal systems, the French regions 
do not exercise leadership over other local authorities; if anything, the French regions are dependent upon the co-operation of lower-level authorities - the departments in particular - for the successful implementation of their own policies.

Constitutional provisions provide strict boundaries within which the regional public sphere has developed ${ }^{\mathrm{I}}$. By creating directly elected regional councils, however, the decentralization reforms of the early ig8os added a significant player, whose influence should neither be overstated nor underplayed. The Regions soon proved themselves determined to develop their policy capacity and expertise as part of a broader process of institution building (Nay 1997). From the early years of the French regions, empirical studies have uncovered institutionalized forms of interdependent relationships in areas as diverse as education (Dupuy 2010), higher education (Aust and Crespy 2009), employment and training (Berthet 2010), transport (Barone 2008), regional languages (Harguindéguy and Cole 2009) and others. Regional institutions established themselves first through investing in public policy delivery and demonstrating that they were viable partners of the State.

What we label as a 'networked institutionalist' approach emphasizes in part the adaptation of the public action registers and traditions of cooperation to new political and institutional circumstances and scales, particularly as a result of decentralization reforms of the early ig8os and the development of a more Europeanised policy space. The networked institutionalist approach rests above all on the argument that the analytically distinct processes of administrative and political decentralization have facilitated the emergence of a regional public sphere, by which is signified an arena within which a plurality of organisations interact: namely local and regional authorities, regional prefectures, representatives of the EU Commission, ministerial field services, associations organised on a regional basis, firms and sometimes social partners (Pasquier 2010; Dupuy 20I0; Barone 2008).

The core dimensions of the reemergence of a regional public sphere are: first, the institutional and policy ambitions of the regional councils; second, the creation of new forms of resource interdependency as a by-product of the gradual empowering of the regional councils in areas such as education, training and transport; and third the processes of rescaling whereby the policy space has become more complex and multi-layered. The players involved in inter-organisational networks extend well beyond the former 'dual elite' of politicians and civil servants and they interact at different and variable scales. The rescaling dimension is important, insofar as the key policy relationships referred to above (in higher and secondary education, training, transport, EU regional policy, even health) occur at the urban or regional, rather than departmental levels. In addition to these new dimensions, we uncover evidence of the creation of robust informal networks 
between regional prefects and the presidents of regional councils, the 'new' notables, though by definition these relationships are variable across the country. In sum, our observation of interactions between regional prefectures, regional councils and non-state actors lends qualified support to a French version of multi-level governance.

\section{State-Region Planning}

Networked institutionalism is formally based mainly on the linked but separate processes of the State-Region plans and EU planning. StateRegion planning has its origins in the 1982 decentralisation law (Gaudin I999). Under the terms of the I982 law, the regional council first draws up a regional plan and then negotiates with the State-in-Region, represented by the regional prefecture. Henceforth, a proportion of the regional councils' budgets, ranging from $15^{-25}$ per cent, is devoted to items co-financed by the regions, the state and the EU. The mode of financing the State-Region plans, and of selecting projects, derives in part from a logic of central steering, the 2007-2013 contracts in particular being closely guided from the centre (Lerousseau 2008). State-Region plans could never, however, be reduced to crude central steering. Existing studies demonstrate a variety of situations across French regions (Kada and Muller-Quoy 20II; Pasquier 2010; Nay 1997), but the basic rule is one of interdependency of state and region; if the State retains the key technical expertise, the regions have the budgets. Evidence gathered in 1995 and 200 r revealed that regions could refuse to agree to the State's demands, or put pressure on the State to contractualise in areas it had not envisaged. ${ }^{2}$ All actors involved are under pressure to agree the StateRegion plans because agreement opens up the prospect of match funding from EU structural funds. Moreover, the process itself encourages the regional state and the elected regions to support each other's claims for territorial ascendancy; in the negotiations for the 2007-2013 projects, the regional prefects negotiated with the regions only, rather than contractualising with departments or inter-communal bodies (Pontier 2007).

\section{The European funding dimension}

The process of negotiating EU structural funds has also strengthened networked institutionalism. The rules of EU structural funds institutionalise the regional State-Region partnership. From I988 onwards, traditional methods of encouraging spatial developments were adapted to fit the EU's funding rules (based on partnership, concentration and additionality, see Smith 1995). In particular, the pluri-annual planning of development objectives and funding mechanisms usually led to more detailed negotiations between the different public authorities and social actors (associations, 
chambers of commerce) involved. New relationships between local actors, the state administration and representatives of the Commission had to be forged in each region (Pasquier 2009). In practice, negotiating and implementing EU cohesion funds necessarily introduces a degree of autonomy from Paris. At the project selection phase, core negotiations are carried out in meetings between regional prefectures, the regional councils and representatives of the European Commission. As the SGAR in Nord-Pas-de-Calais pointed out, in an interview in I994, the precise details of the negotiations took place between the regional State, the regional council and representatives of the Commission (though a representative of the central agency, then the DATAR, was always present in all meetings and any 'multi-level' agreements had to be approved by Paris). ${ }^{3}$

In comparative terms, France retains a state-centric mode of managing structural funds, in which the regional prefectures remain officially the managing authorities. On the ground, the situation is rather more nuanced than this. The Regions and the regional prefectures usually co-chair the Programme Monitoring Committees that determine the selection and evaluation of grants. In the 2007-2013 round, moreover, French regions were able to obtain the direct management of 30 to 50 per cent of the ERDF funds on their territory through the block grant ('subvention globale') procedure (Pasquier 2009). Available evidence suggests contrasting patterns in different French regions. In Alsace, management of structural funds was completely devolved to the regional council, as part of the 2003 experimental transfer of powers procedure. In Brittany, the SGAR and the Regional Council have co-managed EU regional policy in a way that is largely consensual (Smith I995). In Ile-de-France, on the other hand, the Regional Council is not a major player, and the SGAR consults mainly with the mayors of large cities and the other prefectures (Pasquier 2010).

\section{Informal Institutions}

Understanding informal institutions, finally, is required to make full sense of regional diversity. In the case of Brittany, a long tradition of collaboration between State and regional elites goes back to the early postwar period and remains present in the discourse of actors. In this region, existing registers are adapted to deal with new challenges. The Brittany regional prefect admitted, in 2010, that 'I usually have dinner with President Le Drian once a month or so, along with the SGAR and the General Director of the regional council'. The 'network' identifies priorities that go beyond the traditional staple of the state-region plans. In the case of Brittany, the regional State and the regional council claimed to be cooperating on energy policy, specifically on wind turbines and solar power. The prefect and the president of the regional council had been working for 
'months' on a Breton energy programme, with the electricity provider EDF. ${ }^{4}$ This account is striking in that it identifies modes of informal interaction that underplay the importance of partisan attachments (the Socialist President of the Brittany regional council cooperating with the UMP-designated regional prefect).

\section{Countervailing Pressures}

There has not been a clear linear progression in the development of a regional territorial space. In some regions (e.g. Brittany, Nord-Pas-deCalais, Alsace, Poitou-Charentes, Corsica, Rhone-Alpes) it has been more marked than in others. The variability is in part explained by spatial differences; in small regions where there are only two departments (for example Basse-Normandie or Limousin), the departmental level carries more weight than in larger regions, such as Rhône-Alpes, where there are up to eight departments. Political and functional dynamics have also affected the development of regions. Politically, regionalization has been in retreat since the left's clean-sweep in the 2004 regional election and the reaction of the Gaullist-led (UMP) governments in two recent 'decentralisation' Acts of 2004 and 2010. In the law of ${ }_{13}$ th August 2004, the regions were certainly strengthened in matters deemed to be strategic: economic development, education, training, transport and some health. But major service delivery responsibilities were also transferred to the departments, which took over most roads and increased their responsibilities in social welfare, income support and intermediate education. This 'victory' of the departments could in part be explained by political choices, the departmental level being less dominated by the left. But the main argument is an institutional one based, to borrow the language of historical institutionalism, on path dependent change. The previous 1982 reforms had created a much more sophisticated administrative infrastructure for the departments than for the new regional councils; the departments had more capacity, as tested service delivery organizations with large staffs and budgets, than the regions, a functional concern which weighed heavily in the decision to transfer new responsibilities to them.

Neverthless, even though the countervailing pressures have been substantial, they do not undermine the central features of the developing networked institutionalism as outlined above. Moreover, how relationships between levels play themselves out is in part behavioural, contingent on the specific professional, political and functional dynamics in different spaces. From the above survey, it emerges clearly that the regionalization of public policy stakes provides one important dimension of the politico-administrative interactions. But ultimately, as prefects derive their legitimacy from the state, their margins are bounded. The next section brings the analysis squarely back to interactions within the French State. 
State Productivity and Implementation: the Reform of the Territorial State, 2007-20IO

Through close observation of the regional prefectures in particular, the article has thus far engaged with the uneven emergence of the regions as spaces for public policy. This ought not, however, to imply uncritical support for new forms of territorial regulation. The reform of the territorial State under Sarkozy (2007-20I0), the object of this section, was above all concerned with empowering the regional level of the state, without much reference to broader territorial networks. Indeed, the territorial state reform was not accompanied by a strengthening of the elected regions in the 2010 local government reform (Cole 20II). The positive sum qualities of state-regional cooperation had been called into question, from the perspective of President Sarkozy, by the left's victory in the 2004 and 2010 regional elections. In the context of a sharper political division between left and right, why strengthen the regions, and thereby multiply potential veto players?

\section{The 2007-IO Reforms}

In July 2007, François Fillon's Government (2007-) launched a General Public Policy Review (Révision Générale des Politiques Publiques - RGPP) and included change in the territorial state (Réforme de l'Administration territoriale de l'Etat - RéATE) as part of this overarching reform. In its first report of December 2007, the Policy Review's Modernisation Council declared that the State organizes itself first and foremost on a regional basis (Prime minister 2008a). By merging existing bureaux, reducing the number of regional field services from around thirty to seven (eight including the new Regional Health Agencies), and placing them under the hierarchical authority of the prefect, the state claimed henceforth to adopt a more 'strategic' view and to bring the territorial state into line with the mergers taking place at the central, core executive level (Prime Minister 2008a). The second level concerned by the RéATE was that of the 96 departments in mainland France (JO 2008 2009a). From being the 'normal' level of the state's territorial administration, the departmental level was described in a circular of 2008 as a level of local service delivery and implementation of central and regional orientations (Prime Minister 2008b). The reforms redefined the departments around four key elements: the prefecture, the new interministerial divisions (directions départmentales interministerielles - DDI), the 'territorial units' of regional divisions and the new agencies (Kamel 2009). These changes are described in Table $\mathrm{I}$.

The year 20 Io provided a unique opportunity to undertake field work designed to capture contrasting perceptions of the reform at its main levels of operation, perception being central to all versions of new institutionalism. 
TABLE I. The territorial state in metropolitan France

Nomenclature $\quad$ Functions and services

\section{Regional Level}

Regional Prefectures and General Offices for Regional Affairs (SGAR)

Seven streamlined regional services and one new regional agency

\section{Departmental level}

Prefectures

Interministerial directorates for Territory (DDI)

Education

Finances (DDFiP)

The Territorial Units of the regional field services: ARS, DRAC, DiRECGTE

\section{Source}

The 'authority' of regional over departmental prefects is recognized in the decree of I6 February 2010.

The regional level is the normal level of the State's activity and is formally coordinated by the Regional Administrative Committee chaired by the regional prefect

The SGAR obtain new budgetary, management and IT responsibilities and can henceforth recruit their own staff

Food, agriculture and forests (DRAAF); Cultural Affairs (DRAC); Environment, planning and housing (DREAL); Firms, competition, consumers, work, employment and training

(DiRECCTE); Youth, sports and social cohesion (DRJSCS); Education (Rectorat); Finance (DRFiP); Regional Health Agencies (ARS)

Security, elections, legal control, responsibilities not assumed by the other departmental divisions. Henceforth control over the Police and Gendarmerie

The Interministerial directorates for Territory are merged services dealing with infrastructure, agriculture, forests and the environment (DDT)

The Interministerial directorates for Social cohesion and the protection of populations (DDCSPP) are merged services dealing with competition, consumer protection, anti-fraud protection and vetinary services.

In large departments, there are generally separate offices for Social Cohesion (DDCS) and Protection of the Population (DDPP)

The 96 Academic Inspectors and their services retain control over primary and some secondary education

The departmental office of the Finance Ministry

Henceforth under operational control of the departmental prefects, subject to decisions in the Regional Administrative Committee

'L'avancement de la réforme de l'administration territoriale de l'État', Révision Générale des Politiques Publiques, I2 mai 2009 (http://www.ropp.modernisation.gouv.fr), 'Quatrième Conseil de Modernisation des Politiques Publiques' June 2010, RGPP: Paris.

While acknowledging that we must exercise caution before attributing longlasting consequences to such recent changes, we would expect officials in the prefectures to adapt to the new structures over time.

Respondents for interviews in various relevant bureaux at central government level in 2010, as well as sustained analysis in the French region of Brittany, were chosen mainly in order to capture temporal evolution with earlier fieldwork in 1995 and 2 OOI $^{5}$. Simultaneously, a survey of all 
departmental and regional prefectures was carried out from January to June 2010 by a working group of the Groupement de Recherche sur l'Administration Locale en Europe (Research Group on Public Management in Local Authorities in Europe, GRALE) (Kada and Muller-Quoy 20II; Muller-Quoy 2010) ${ }^{6}$. The analysis thus drills down from central via regional to departmental level. It captures the perceptions of state officials working at the level of senior management in the prefectures and new interministerial directorates. In the GRALE survey, the prefectures of all 96 departments and 22 regions of mainland France were targeted via a postal questionnaire, complemented in places with follow-up interviews. The response rate was limited for the regions, as only six out of 22 returned questionnaires (Haute Normandie, Rhône-Alpes, Franche-comté, Provence-Alpes-Cotes d'Azur, Centre and Picardie) but 47, nearly half of the departments, responded. The weighting of the survey in favour of the senior managers in departmental prefectures allowed a pure 'prefecture' perspective to emerge, counter-balanced somewhat by the interviews at regional and central government levels.

We will now consider the reform of the territorial state from 2007 to 2010 from our three perspectives of decision-making, sense-making and interactions, thereby engaging fully with the varied, and sometimes contradictory facets of the prefectures as organizations.

\section{Decision Making}

The first entry point for understanding the RéATE is that of decisionmaking, and specifically short-term institutional design. The institutional design school, associated particularly with rational choice institutionalism, believes in the virtues of synoptic reform, involving a clear association of causes and effects, the most efficient choice of policy instruments to guide behaviour and providing clear incentive structures to ensure conformity (Peters I999; John I998; Goodin 1995). The reorganization of the regional and departmental levels of the French state machinery was presented as a product of a synoptic institutional design, conceived in order to limit capture by interest groups and reduce the number of veto points within the administration. It was driven by an overarching narrative of state productivity closely associated with President Sarkozy, and with the chief of his presidential office, Claude Guéant, himself a member of the prefectoral corps.

Strengthening the regional level was trailed as the main object of the 2010 reform (JO 2010). The regional level is now the 'normal' level of activity of the state. The departmental level is confirmed in its traditional functions of law and order and immigration, but all other policy fields (whether implemented at the departmental and regional level) are placed under the authority of the regional prefect. For the first time, the decree of 
I $6^{\text {th }}$ February 2010 affirms that the regional prefect has 'authority' over the departmental prefects. Moreover, using the power of revocation ('evocation'), the regional prefect can exercise responsibilities normally reserved for the departmental prefectures for a limited period of time. Such a clear affirmation of the ascendancy of the regional over the departmental level goes much further than any previous moves to strengthen the regional prefectures. The claim to regional state leadership is strengthened by the creation of the Regional Administrative Committee (Comité d'administration régional - CAR), chaired by the regional prefect. Described by one interlocutor as an executive board of the state, the CAR brings together the directors of the seven new regional services, as well as the head of the Regional Health Agency and the departmental prefects. Though the regional prefect has to consult with the CAR in relation to matters such as human resources policy, the distribution of credits across départements, or performance indicators, she alone is responsible for publishing the State's Strategic Action Plan (Plan d'action stratégique de l'État en region - PASER), henceforth the key document that serves as a tool to contractualise with the local authorities.

The regional prefectures are strengthened in their own capacity as organizations. Moreover, a strong case can be made of the regional level obtaining the instruments allowing authoritative decisions to be made. The regional prefectures, created in I964, were initially light, strategic bodies that attempted to coordinate the activities of the much weightier departmental prefectures (Kada 2008). Most service delivery and regulation was ensured at the departmental level. The key services that the regional prefects called upon were the General Secretariats for Regional Action (Secrétariat général de l'Action régionale - SGAR). For most of their existence, the SGAR have demonstrated the limits to the regional prefects' claim to exercise strategic state leadership. Though they were attached to the regional prefectures, the SGAR were undermined by tensions brought about as a result of the corps loyalties of their members. ${ }^{7}$ The prefect's advisors in the SGAR were split between those belonging to the prefectoral corps and policy experts seconded mainly by the technical corps - Highways and Bridges notably - who exercised a large degree of autonomy. The SGARs nonetheless came into their own in the post-decentralisation period, where they performed a lead role in coordinating State responses in the six-yearly State-Region planning contracts and, later on, in writing the Single Programming Documents for the EU cohesion funds. They were strengthened greatly by the 2007-20I0 reforms. They were transformed into more substantial administrative structures, for the first time in charge of their own recruitment. From January $\mathrm{I}^{\text {st }}$ 20II, moreover, the SGAR administer a streamlined budget (BOP 333) that distributes operational credits to the regional and departmental field services (JO 2009b; Interior Ministry 2010). ${ }^{8}$ 
With their stronger organizational and legal resources, the regional prefectures' claim to exercise territorial leadership is one that is apparently given substance by new instruments of financial monitoring and regulation. One potential lever to allow the regional prefect to impose his authority is that of the LOLF (Loi organique relative aux lois de finances), the 'new' budgetary law operational since 2006. Under the LOLF, the regional prefects are budget holders, formally charged with distributing operational resources to government agencies and services coming under their hierarchical control. The regional prefectures control the budget programmes (BOPs, budgets opérationnels de programme) concerned with territorial administration (BOP 307), along with the separate operational budget (BOP 333) administered by the SGAR (Interior Ministry 20I0). Vesting theoretically powerful institutions with more constraining and precise regulatory instruments is clearly intended to enhance their substantive, rather than purely procedural, capacity to coordinate the State's territorial activities. But the impact of any particular instrument can not be considered in isolation; the effectiveness of these new financial controls in particular is curtailed by the role of the Budget and Public Accounts Ministry considered below.

How were these broad policy objectives received amongst officials in the prefectures? In the survey and interviews, officials acknowledged the economic arguments for rationalising the state machinery. Yet most respondents expressing an opinion were unconvinced that the expressed aims of the reform would be achieved. Most managers (two-thirds of respondents) believed that the reform of the territorial State was above all designed to reduce the number of staff in a zero-sum spiral. Officials in the departmental prefectures complained about losing resources as a result of regional state centralisation. They feared shedding jobs to the new DDI, while managers in these new divisions were anxious about losing their key agents to the new regional services $^{9}$. These experiences raised deeper issues of appropriate behaviour that are now considered.

\section{Making appropriate sense}

Our second entry point for understanding the RéATE is that of the logic of sense making. In their seminal book, March and Olsen (I989) defined institutions in terms of 'logics of appropriateness', referring to the internal cognitive dynamics that bind individuals to organizations and sustain them. From this perspective, institutions are primarily important because they embody prevailing ways of understanding the world, which are closely linked with perceptions of individual self-interest (Schmidt 20го; Hay 2006; Rouban 2003). March and Olsen (I989) also acknowledged that logics of consequentiality might come into play - the conscious rational assessment of costs and benefits and likely consequences of choices. But 
what characterizes an institution is more likely to pertain to perceptions of norms, the representation of the correct roles that ought to be performed by officials and rule-bound behaviour.

The prefectoral corps in France is particularly interesting in this respect (Tanguy 2009). Most prefects form part of a specific corps within the state; with its own precise identity, sense of appropriate behavior and proud history, and the prefectoral corps can demonstrate professional continuity for over two hundred years (see Tanguy 2009; Pontier 2010; Machin 1976). Yet, in key respects, their collective influence has waned over the past decades. The prefectoral corps has been divided, as the result of an unresolved tension between the regional and departmental levels. Most departmental prefects and sub-prefects opposed the creation of the regional prefectures in I964, resisted any hierarchy within the corps and experienced regionalization as a zero-sum game (Machin 1976). Above all, the prefectures admitted to being 'traumatised' by the consequences of decentralization in the early $1980 \mathrm{~s}^{\mathrm{IO}}$ Perceptions of logics of appropriateness thus provide a fruitful angle for raising important questions about professional dynamics within the prefectures and the persistence of corps-based identities within the state, as well as the challenges represented by pressures towards multi-level governance.

Respondents to the GRALE survey addressed questions about professional cultures, staff duties, or the implementation of the reform that involved appreciations of appropriate behaviour. At its most elementary, the belief was widespread that managers in the prefectures ought to conform to central directives and circulars, perhaps a predictable stance by officials of the Interior ministry. All departments and regions which responded reported having applied the national directives and reorganised their services. The administrative map of France was rationalised and, indeed, made far more uniform than at any previous stage, particularly at the regional level where there are now identical services in all regions (except Ile-de-France). Most managers who expressed an opinion in the open-ended section supported the reform insofar as it was interpreted as strengthening the visibility of the State and reducing administrative duplication. There is a suspicion that appropriate responses were seen as part of appropriate behaviour; most were content to follow the government and attribute the reform to the economy drive of the RGPP. This note of methodological caution itself highlights the normative attachment to the idea of public service and the State as guarantor of the general will.

Appropriate behaviour suggests a general understanding of roles and public service. Once the questioning moved down the ladder of abstraction, more critical comments appeared that were motivated by an understanding of the ethos and expertise of public service. Though officials declared themselves favourable to the RGPP, they were strongly opposed to some of its practical consequences. Evidence from the departmental prefectures 
suggested that there had been very little 'contracting out' of key services such as buildings and vehicle maintenance (though this was envisaged as one likely outcome of the RGPP). ${ }^{\text {II }}$ Most significantly, the new regional health agencies were considered, in several responses to open-ended questions, as an administrative aberration that contradicted the reform's declared aim to rationalise and strengthen the prefectures. These perspectives from the field identified one of the core tensions of the reform; creating independent agencies while enhancing a rather traditional state steering role.

These tensions spilled over, in face to face interviews, to tensions between levels. From the perspective of departmental managers, with new powers of 'evocation' and budgetary oversight the regional prefect would henceforth be able to determine the distribution of finances and services between the regional and departmental levels. There was a fear, from the departments, that the regional prefects would systematically favour the regional level; that the best elements would drift to the regional services, and that the DDI would not have enough agents to fulfil their basic tasks (Direction départementale des Territoires et de la Mer and Ile-et-Vilaine 2010). This rivalry between levels was moderated, however, by countervailing professional dynamics, the regional and departmental prefects remaining part of the same corps. In the 22 regional capitals, there is still no separation between the regional and departmental prefectures, with the regional prefect in practice delegating the management of departmental affairs to his general secretary. Creating a collective leadership of the regional state challenges the overarching sense of corps loyalty, but professional loyalties are mediating the process of territorial state reform. A cogent example was provided by one regional prefect, who admitted convening an informal meeting limited to the regional and departmental prefects in the morning that would continue over lunch where subjects would be 'freely debated' before a more formal meeting occurred with the directors of the regional services in the Regional Administrative Conference itself (Préfecture de Région Bretagne 2010) ${ }^{12}$.

Another measure of appropriate behaviour related to an agent-centred preoccupation with roles and grades. The survey and the author's own fieldwork in the Ile-et-Vilaine department (Brittany) revealed serious difficulties of cultural adaptation, especially as a result of mergers in the new interministerial departmental services. Enforced mergers brought together bureaux which 'do not share the same administrative culture' or ways of working, such as the reorganisation in the new interministerial directorates for social cohesion and the protection of populations (DDCSPP - Direction Départementale de la Cohésion Sociale et de la Protection des Populations) that brought together animal health and sports services within the same structure (Kada and Muller-Quoy 20II). The main issue, however, was one of statutes. Though agents were housed in the new structures, they remained attached to their corps of origin, with specific terms, conditions and rates of 
remuneration depending upon which corps they belong to. Different collective agreements have governed staff mobility across services. The mixed commissions (commissions administratives paritaires - CAP), which have to approve changes of working conditions, operate only at the national ministerial level, and they vary between ministries. Hence the new DDI have little control over the terms and conditions of their agents. As a result, though departmental services were intended to join up services on the basis of broad areas of service delivery, organisational silos have persisted.

From this account, the reform of the territorial state conflicted with the traditional role perceptions of agents within the prefectures, who were fearful of the material and status consequences of what was perceived as the regionalisation of the territorial state and the creation of unwelcome new institutional forms such as agencies. The prevailing corps ethos continued to matter and served to smooth the effects of a net division between regional and departmental levels...for the moment. The evidence presented here suggests that the prefectoral corps itself has always been divided about institutional reform, but has lacked the capacity to prevent the clearer emergence of regional prefects as something akin to a grands corps of senior civil servants close to those in political authority.

\section{Interactions; from networks to hierarchies}

Our third perspective for understanding the RéATE is that of interactions. Thus far the analysis has revealed two rather contrasting logics that correspond to the twin faces of state reform. Networked institutionalism involved the strengthening of networks between politicians and regional prefects and - at its strongest - the emergence of a regional public sphere. Regional prefects performed an ambiguous role, whereby building resources in alliance with non central state partners facilitated a degree of autonomy. The reform of the territorial state from 2007-2010 proceeded, however, from a state productivity logic, involving a primary concern with the State's own operation and a NPM-style register based on targets, verifiable information, performance indicators, and a clearer identification of centres of decision-making and accountability. An emphasis on state productivity also implied a challenge to more traditional forms of stateregional cooperation, demonstrated by the outcomes of the 2010 local government reform which markedly failed to strengthen the competencies of the elected regions. While this decoupling of state and territory might make sense from a central steering perspective, it undermined the claim of regional prefects to mediate forms of vertical and horizontal coordination.

Far more than producing an easy clarification, the 2007-2010 reforms revealed deep structural rivalries based on rival claims of coordination within the French State. There are at least two key obstacles in the way of 
the regional prefect's horizontal claim to coordinate government activity. First, the vertical structure of most sectoral activity; government departments, and ministers in particular, still seek to give orders to their territorial services. Within the State, the coordinating claims of the prefectures run against the vertical organisational structure represented by the central ministries in Paris and their external services. The central ministries now retain agents and services only at the regional level, their departmental services having been, to all extents and purposes, dissolved. As the regional level is now the only level where the Paris-based ministries can directly intervene, it was suggested in several interviews that the lead ministries were seeking to exercise a tighter control over their regional services than they had previously thought necessary. ${ }^{\mathrm{I}}$

Second, more specifically, in relation to the role of the Finance and Budget and Public Accounts ministries. Relations between prefects and representatives of the Finance ministry have invariably been poor, as Machin (1976) demonstrates. The Finance ministry has resisted attempts to enhance prefectoral coordination. A step change came with the new budgetary law of 200I (operational since 2006), the LOLF. Though it did not initiate this reform (driven by a cross-party alliance of deputies seeking to enhance parliamentary control over government expenditure), the Finance ministry's Budget division (later ministry) was anxious to control its implementation. One interlocutor in the associated Budgetary Reform division explained in some detail why central government felt it necessary to exercise a close supervision over lower levels of the State: 'the central administration has an important role to play in ensuring the coherence of public policy, and in monitoring the budget. We are reluctant to allow the field services too much autonomy'. ${ }^{14}$ This distrust spilled over into a resistance to allowing the regional prefectures full control over decentralized state budgets. Though the LOLF enhances the regional over the local levels, the bulk of resources distributed via the regional prefectures are ring-fenced for specific services and government agencies $^{15}$. The Budget and Public Accounts ministry has thus made its presence felt as the core vertical coordinating force, using the budgetary instrument to confine and control the territorial state (Bezes 2009, DGME 2010).

The vertically focused French state has always placed obstacles in the way of genuine coordinating powers for the prefectures. Prefectoral claims have had to face rival modes of state coordination; those based on sectoral control (ministries and their field services), budgetary instruments (the role of the Finance ministry), professional identities (the system of competing and rival corps within the State) and political leadership. Rival modes of state coordination remain very present and, indeed, they respond to the core features of the French state itself. Moreover, as in the case of the LOLF, policy instruments can develop their own path dependent logics that tie-in future reforms. If the examples above are drawn from empirical 
fieldwork in France, they elucidate more generic cross-national issues of territorial, fiscal and functional coordination; and especially the centralising impact of new budgetary policy instruments across (and beyond) states in the euro-zone.

\section{Discussion}

Studying the prefectures gets to the heart of the nature of the contemporary French state. The article addressed the core research question: what are the conditions for institutional resilience and adaptation in a period of state restructuring and rescaling? Our case study of the prefectures as old institutions was framed using the language and analytical tools of new institutionalism, specifically across the three dimensions of the temporality of decision-making, sense-making and interaction.

These three sub-fields each offer partial responses to this core question. The temporality of decision-making dimension allows distinctions to be drawn between different timescales; from the longue durée of institutional genesis and evolution to the short-term timescale of a specific reform (the RéATE). Historical institutionalists offer two main types of explanation for institutional resilience: the path dependent and the evolutionary (Steinmo 2008). Path dependent explanations emphasise how organizations are originally constituted, in particular the rules they embody and values they represent. A decision-making variant of path dependency stresses that decisions taken early on in any process help to define the possibilities for further evolution (Pierson 2004). Evolutionary explanations borrow analogies from the natural sciences to explain why certain institutions survive and why others fail. Survival is a function of adaptation to a changing environment: in the words of Steinmo (2008: I28) 'the historical institutionalist is something like an environmental biologist who believes that in order to understand the specific fate of a particular organism or behaviour, she must explicitly examine that organism in the ecology or context in which it lives'.

What purchase do these ideas have for our case? The weight of historical creation in shaping institutional design is extremely important. The Napoleonic model that emerged towards the end of the French revolution required a symbolic homogeneity of French society; this constitutive act vested the office of the prefect with the enduring values of embodying the general interest in France's territories. As the article has demonstrated, however, reasoning in terms of genetic codes has many limitations, not least insofar as it underplays the capacity to engage in learning or to survive by evolution. The decision-making dimension is more central to our case study. The prefectures classically formed part of a departmental structure vested with its own path dependent logic. The traditional weight of the departmental prefectures has been modified by the rise of the elected 
departmental councils as major service delivery agencies, especially since I982. But, in one reading, political and administrative decentralisation has been narrowly confined to the traditional departmental circuits which have emerged stronger from successive reforms (Procureur 20II). These analyses illuminate the tensions within the prefectoral corps, as well as the existence of rival territorial networks to those described in terms of the regional public sphere. The broad historical context is also key to understanding the dynamics of any specific reform, such as that of 2007-2010, beset by problems of policy implementation and the unintended consequences of past decisions. More generally, the weight of history greatly contributes to understanding how the French State continues to combine rival vertical, territorial, professional and bureau-shaping logics.

On the other hand, the 2007-20I0 reforms represented a step change in the regionalisation of the state, the apogee of a long evolution in the postwar period. More precise legal and regulatory instruments strengthened the capacity of the regional prefectures to coordinate the State's territorial activities. In the past decade the prefectures have evolved within the French State in the context of a discursive shift towards state productivity. These trends came to a climax in the first Sarkozy presidency of 2007-2012; hence the attention paid to the reform of the territorial state under Sarkozy and the extensive reflection on the nature of institutions in a multi-level context. In practice, we argued that the language of state productivity empowers other players, renders less credible the discourse of territorial coordination and embeds budgetary actors as the key coordinators of the State. Rather paradoxically, the post-2007 environment appeared somewhat less conductive to building the territorial regimes that had emerged in the first two decades after decentralization in spite of the formal strengthening of the authority of the regional prefectures. Arguments based on path dependency are important but do not, in themselves, explain the emergence of the regions as policy spaces and the role performed by regional prefects therein, nor, indeed, the managerial turn operated by Sarkozy.

A second partial response to the question of resilience lies in understanding the policy worlds of actors. Drawing from sociological institutionalism, the French prefectures can be understood as a professional corps. The corps are very distinctive groups within the French State, a set of self-regulating elites that jostle for ascendancy and influence within (and beyond) the state and seek to preserve their influence against rival (especially lesser ranked) corps. The evidence presented here suggests that the prefectoral corps has been divided, as the result of an unresolved tension between the regional and departmental levels; a varying reaction to decentralization, and a strategically distinct stance to rescaling by the departmental and regional levels. Though the sense of corps still provides a veneer of overarching cohesion, our discussion suggests that the collective influence and identity of the prefectoral corps has waned 
over the past decades. Professional logics within the state, embodied in the corps, have proved tough to reform. As Gervais (2010) demonstrates, however, professional identities are not static and do not preclude either evolutionary or anticipatory behaviours by actors within the state. Arguments based on logics of appropriateness are necessary, but not sufficient for understanding why institutions persist.

This conclusion points to a third form of explanation, whereby resilience demonstrates a capacity to adapt to a changing environment. Far from static representations of roles, beliefs and genetic codes, the prefectures are best understood in action and interaction. The main contribution made by this analysis is in terms of interactions, in a process I describe as that of networked institutionalism and that accommodates the idea of evolution through interaction. My main argument is that prefects in France have proved resilient in part because of their strategic positioning as mediators in the management of political and administrative decentralization, a centrality that has given rise to forms of networked institutionalism. Through close observation of the regional prefectures in particular (but not exclusively), the article has engaged with the emergence of the regions as spaces for public policy and the engagement of the regional level in processes of territorial state reform throughout the Fifth Republic. In the post-decentralisation period, prefectoral authority was revived in the context of an imperfect pattern of territorial decentralisation, one based on the survival and partial rescaling of parallel political and administrative filières. As territorial policy actors, regional prefects benefited in particular from the new structure of opportunities opened by decentralisation, State-Region planning and EU regional policy. In these fields, at least, decentralisation in France was framed in terms of distinct but interdependent state and regional spheres - the latter gaining in capacity insofar as the former increasingly formalised interactions at the regional (rather than departmental) level. What we describe as networked institutionalism encapsulates the form of cooperation between networks in the restrictive setting of the French unitary state. It gives substance to arguments that accept the utility of reasoning in terms of a modified version of multi-level governance in the French case.

In sum, a 200 year old institution is best understood in through a hybrid interpretation. The core dimensions are those of the temporalities of institutional design (both in terms of longue durée and in response to specific reforms), the values and interests of actors (non-constant and variable according to position within the corps), and the interdependent relationships that, in practice, constrain the operation of institutions. We contend that logics of decision-making, appropriateness and interaction are rarely consistent; understanding the prefectures as organisations empirically requires revealing the tension between these dimensions, as well as demonstrating how they might be combined. Beyond the narrow case of the prefectures in 
France, the article makes the case for combining modes of institutionalist analysis in order to penetrate beyond generalities into the black box of real institutions, which, of necessity, need to be contextualised. Institutional design (decision-making) has always had to contend with normative and cognitive reactions based on notions of appropriateness (sense-making) and this case confirms that the cognitive and normative worlds of managers working in prefectures provide a very specific context through which rational reform designs are filtered. Above all, making sense of institutions requires an understanding of their interactions, and their strategic capacity to adapt to change (understood both as exogenous and endogenous) and to respond to evolutionary pressures.

\section{NOTES}

I. The constitutional provision ensuring the 'free administration of local authorities' (compétence générale d'administration) prevents any hierarchical control of the regions over other levels of sub-national authority.

2. For example in relation to old age people's homes.

3. Interview in 1994 (SGAR Nord/Pas-de-Calais). 'The regional prefect is the interlocutor of Brussels for the regional single programming documents. Negotiations take place directly between the regional prefect and the Commission. It's the same thing for the expenditure of the EU grants; the central State no longer has anything to do with it'.

4. This account is based on information provided by the Brittany regional prefecture.

5. Earlier fieldwork was carried out as part of two separate ESRC projects 2001-2003 'Devolution and Decentralisation in Wales and Brittany' (Grant no. L2I9252007) and 'Local Policy Networks in Britain and France' (Grant no L3II253047, with Peter John)

6. Groupement de Recherche sur l'Administration locale en Europe, a CNRS-accredited research institute mainly funded by the French Interior ministry. Surveys were addressed to all regional and departmental prefectures in mainland France. The overall response rate ( 53 responses from in8) fell someway short of $50 \%$. This provides a rich data set with which to complement the case study analysis undertaken by the author.

7. This theme emerged in interviews in two French regions in I994-96.

8. But these inter-ministerial bodies remain administrative lightweights; doubts were expressed in interviews within and beyond the SGAR that they would be able to perform the new functions vested on them: 'The SGARs still have little real capacity'. Interview, 20 Io.

9. 'Any new jobs are going to the regional level, we are losing jobs' Interview, 20 o.

IO. The expression is that of the General-Secretary of an important prefecture interviewed in I994.

II. Muller-Quoy (20I0) reports this finding

I2. Interview, 2010 .

I3. 'In fact, the regional field services still receive directives from their ministries' Interview, Ministry of Finance's Budget division, 2010.

I4. Interview, Budgetary Reform division, Finance ministry 2005.

I5. Confirmed in interviews at central and regional level in 20I0. This limits the significance of the principle of fungibility that ought to benefit the regional prefect.

\section{REFERENCES}

Aust J. and Crespy C. (2009) Napoléon Renversé? Institutionalisation des PRES et réforme du système académique français. Revue Française de Science Politique 59(5): 915-938.

Barone S. (2008) Le Train des régions. Régionalisation des transports collectifs et recompositions de l'action publique. Unpublished PhD dissertation. University of Montpellier I.

Berthet T. (2010) La Formation professionnelle des régions. Une compétence discrète pour une capitale politique accrue, Paper presented at the Nouvelles Perspectives sur les politiques régionales colloquium, University of Montpellier I, 29th January, pp. 20. 
Bezes P. (2009) Réinventer l'Etat. Les réformes de l'administration française. Paris: PUF.

Burnham J. (2009) Politicians, Bureaucrats and Leadership in Organisations. Lessons from Regional planning in France. Basingstoke: Palgrave.

Chapman B. (1955) The Prefects and Provincial France. London: Allen and Unwin.

Cole A. and John P. (200I) Local Governance in England and France. London: Routledge.

Cole A. (201 I) The French State and its territories, Public Administration (forthcoming).

Crozier M. and Thoenig J.-C. (I975) La Régulation des systèmes organisés complexes. Revue française de Sociologie I6(I): $3^{-} 3^{2}$.

Delcamp A. and Loughlin J. (2002) La décentralisation dans les Etats de l'Union européenne. In Delcamp A. and Loughlin J. (eds.), La decentralisation dans les Etats de l'Union européenne. Paris: La Documentation Française, I I-26.

Direction de la Réforme budgétaire (2005) Interviews with x.

Direction départementale des Territoires et de la Mer, Ile-et-Vilaine (20I0) Interviews with x.

Direction du Budget (2010) Interview with x.

Direction générale de la Modernisation de l'Etat (DGME) (20I0) Interviews with x.

Direction régionale de l'environnement, de l'aménagement et du logement (DREAL), Brittany (20Io) Interview with $\mathrm{x}$.

Dupuy C. (2010) Politiques publiques, territoires et inégalités. Les politiques régionales d'éducation en France et an Allemagne (1969-2004). Paris: IEP, unpublished $\mathrm{PhD}$ dissertation.

Duran P. and Thoenig J.-C. (1996) L'Etat et la gestion publique territoriale. Revue Française de Science Politique 45(4): 580-622.

Gaudin J.-P. (I999) Gouverner par Contrat. L'Action publique en question. Paris: Presses de Sciences Po.

Gervais J. (2010) Fusionner pour durer? Grands corps techniques et restructurations administratives en France. International Review of Administrative Sciences 76(3): 425-44I.

Goodin R. E. (i995) The Theory of Institutional Design. Cambridge: Cambridge University Press.

Grémion P. (1976) Le Pouvoir péripherique: bureaucrates et notables dans le régime politique français. Paris: Seuil.

Harguindéguy J.-B. and Cole A. (2009) La politique linguistique de la France à l'épreuve des revendications ethnoterritoriales. Revue Française de Science Politique 59(5): 939-967.

Hay C. (2006) Constructivist Institutionalism. In Rhodes R. (ed.), The Oxford Handbook of Political Institutions. Oxford: Oxford University Press, 56-74.

Hayward J. (1983) Governing France: The One and Indivisible French Republic. London: Weidenfeld and Nicolson.

Interior Ministry (2010) L'Etat en mouvement. Directive nationale d'orientation des préfectures. Paris, 78pp.

John P. (1998) Analysing Public Policy. London: Pinter.

Journal Officiel de la République française (2008) Circulaire du 7 juillet 2008 relative à l'organisation de l'administration départementale de l'Etat.

Journal Officiel de la République française (2009a) Décret no 2009-I484 relatif aux directions départementales interministérielles.

Journal Officiel de la République française (2009b) Décret no 2009-587 du 25 mai 2009 relatif aux missions des secrétaires généraux pour les affaires régionales.

Journal Officiel de la République française (20I0) Décret no 20ı-I46 du I6 février 20ıo modifiant le décret no. 2004-374 du 29 avril 2004 relatif aux pouvoirs des préfets, à l'organisation et à l'action des services de l'État dans les régions et départements.

Kada N. (2008) La Régionalisation des préfectures. Pouvoirs Locaux 77(II): 29-34.

Kada N. and Muller-Quoy I. (201 I) Réforme de l'administration territoriale de l'État: les ratés de la RéATE. Actualité Juridique Droit Administratif i 6: 765 .

Kamel W. (2009) Le future visage de l'État dans le département: Une organisation resserrée et modulaire des services déconcentrés. Revue Française d'administration publique I31: 595-600.

Kerrouche E. (I997) L'apprentissage du rôle de sous-préfet. Politix 04/o6(38): 88-I Io.

Le Galès P. (2008) Territorial politics in France: le calme avant la tempête? In Cole A., Le Galès P. and Levy J. (eds.), Developments in French Politics 4. Basingstoke: Palgrave, 235-26o.

Le Lidec P. (2007) Le jeu du compromis. L'État et les collectivités territoriales dans la décentralisation en France. Revue française d'administration publique $\mathrm{I} 2 \mathrm{I}^{-} \mathrm{I} 22$, II I- ${ }^{-} 30$.

Lerousseau N. (ed.) (2008) La Décentralisation à la croisée des chemins. Paris: Harmattan.

Mabileau A. (I99I) Le système local en France. Paris: Montchrestien.

Machin H. (1976) The Prefect in the French Administration. London: Croom Helm.

March J. and Olsen J. (I989) Rediscovering Institutions: The organizational basis of politics. New York: the Free Press.

Muller-Quoy I. (2010) Synthèse des réponses au questionnaire relatif au regroupement des services de l'Etat. Paris: GRALE, 29pp. 
Nay O. (I997) La Région, une Institution. La représentation, le pouvoir et la règle dans l'espace régional. Paris, l'Harmattan.

Pasquier R. (2009) The Europeanisation of French Regions. French Politics 7(2): 123-144.

Pasquier R. (2010) Le Pouvoir Régional. Mobilisations, décentralisation et gouvernance en France. Paris: Institut d'Etudes Politiques de Paris.

Peters B. Guy (I999) Institutional Theory in Political Science: The 'New Institutionalism'. Basingstoke: Palgrave.

Piattoni S. (2010) The Theory of Multi-Level Governance. Conceptual, Empirical and Normative Challenges. Oxford: Oxford University Press.

Pierson P. (2004) Politics in Time. History, Institutions and Social Analysis. Princeton: Princeton University Press.

Pinson G. (2010) France. In Goldsmith, M. J. and Page, E. (eds.), Changing Government Relations in Europe. From Localism to Intergovernmentalism. London: Routledge, 68-87.

Pontier J.-M. (2007) Les contrats de projet Etat-régions 2007-2013. Revue administrative 359: 523-534.

Pontier J.-M. (2010) Le nouveau préfet. Actualité Juridique Droit Administratif I5: 8I9.

Préfecture de Région Bretagne (2010) Interview with x.

Prime Minister (2008a) Réforme de l'organisation des services territoriales de l'État, Circular 5285/SG, dated I9/o3/2008, 3pp.

Prime Minister (2008b) Organisation de l'administration départementale de l'État, Circular 5359/SG, dated 3 I/I2/2008, Iopp.

Procureur T. (201 I) Département. In Pasquier R., Guigner S. and Cole A. (eds.), Dictionnaire des politiques territoriales. Paris: Presses de Sciences Po, I65-170.

Rouban L. (2003) Reformer ou Recomposer l'Etat? Les enjeux sociopolitiques d'une mutation annoncée. Revue française d'Administration publique $\mathrm{IO}^{-\mathrm{I}} \mathrm{-6}$, I53-166.

Schmidt V. (2010) Taking ideas and discourse seriously: explaining change through discursive institutionalism as the fourth "new institutionalism". European Political Science Review 2(I): I-25.

Schondorf-Haubold B. (2007) L'émergence d'un droit commun de l'autonomie territoriale en Europe.

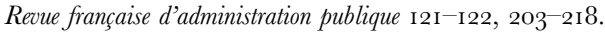

Secrétariat général des Affaires Régionales de la Région Bretagne (SGAR-Bretagne) (20Io) Interview with x.

Smith A. (I995) L'Europe politique au miroir du local. Les fonds structurels et les zones rurales en France, en Espagne et au Royaume Uni. Paris: L'Harmattan.

Steinmo S. (2008) Historical Institutionalism. In Dellaporta D. and Keating M. (eds.), Approaches and Methodologies in the Social Science. Cambridge: Cambridge University Press, I 8-138.

Tanguy G. (2009) Corps et âme de l'état: socio-histoire de l'institution Préfectorale (I880-I940). Unpublished PhD dissertation, University of Paris I.

Thoenig J.-C. (2005) Territorial administration and political control: Decentralization in France. Public Administration 83(3): $685-708$.

Worms J-P. (i966) Le Préfet et ses notables. Sociologie du travail 8(3): $249^{-275 .}$

PROFESSOR ALISTAIR GOLE

School of European Studies

Cardiff University

65-68 Park Place, Cardiff, CFIo 3YQ Wales- UK

e-mail:ColeA@Cardiff.ac.uk. 